\title{
Development and Validation of Inductively Coupled Plasma Atomic Emission Spectroscopy [ICP-AES] Analytical Method for Estimation of Cisplatin in Biological Samples
}

\author{
Shruti Akshay Wagle ${ }^{1 *}$, Darshana Jain ${ }^{2}$, Sudha Rathod ${ }^{1}$, Rajani Athawale ${ }^{3}$, Amrita Bajaj ${ }^{4}$ \\ ${ }^{1}$ Oriental College of Pharmacy, Sector 2, Plot No 3, 4, 5, Sanpada (W), Navi Mumbai, Maharashtra, INDIA. \\ ${ }^{2}$ C.U.Shah College of Pharmacy, S.N.D.T Women's University, Santacruz (W), Mumbai, Maharashtra, INDIA. \\ ${ }^{3}$ Principal K.M Kundnani College of Pharmacy, Plot No. 23, Jote Joy Building, Rambhau Salgaonkar Road, Cuffe Parade, Mumbai, \\ Maharashtra, INDIA. \\ ${ }^{4}$ SVKM's Dr. Bhanuben Nanavati College of Pharmacy, V.M Road, Vile Parle (W), Mumbai, Maharashtra, INDIA.
}

\begin{abstract}
Objective: Cisplatin, a popular anti-neoplastic agent is employed as a first line treatment for variety of cancers. Majority of the analytical methods reported for Cisplatin are either complex or not suitable for routine analysis of the drug. Hence, there is a need for development of suitable analytical technique like ICP-AES for quantitation of Cisplatin in complex matrices and biological samples. Methods: Cisplatin was analyzed in the present study based on its single step conversion to platinum metal with aqua regia. Results: The developed method was validated and was found to be linear in the range of 0.375 to $15 \mu \mathrm{g} / \mathrm{ml}$ with a regression coefficient of 0.992 . The percent recoveries of Cisplatin from plasma and tissue samples ranged from 95 to $99 \%$. Discussion: A simple, low cost, sensitive, one step ICP-AES technique was developed and validated for bioanalytical estimation of Cisplatin.
\end{abstract}

Key words: Cancer, Cisplatin, ICP-AES, Platinum.

\section{INTRODUCTION}

Platinum and platinum containing compounds are of utmost importance for analytical research due to their applications as anticancer agents, catalysts and other medical applications. Cisplatin is one of the oldest platinum containing chemotherapeutic agents employed for treatment of variety of cancers of soft tissues, head, neck, muscles, bones and blood vessels. ${ }^{1}$ Hence, it is a part of first line regimen for chemotherapy despite being associated with side effects like ototoxicity, nephrotoxicity and severe nausea and vomiting with dehydration. ${ }^{2}$ Owing to this, the clinical success of Cisplatin demands the need for its estimation by a $\mathrm{s}$ ensitive and reproducible analytical technique. Numerous analytical methods have been described in the literature for Cisplatin analysis like high performance liquid chromatography, inductively coupled plasma mass spectroscopy (ICP-MS), atomic absorption spectroscopy and quenched phosphorescence detection., Majority of these reported intricate analytical techniques are not reasonable for day-to-day analysis of the drug. Other disadvantages associated with these techniques include high cost of studies, use of additional steps for recovery of the drug and longer time for estimation of drug concentration.

ICP-AES is a versatile method for sub-part per million estimation of plentiful elements like platinum, calcium, rhodium and palladium. It has applications in many areas including bio-inorganic chemistry and pharmaceutical analysis. It is a type of emission spec-
Submission Date: 30-06-2017; Revision Date: 06-07-2017; Accepted Date: 14-10-2017

DOI: 10.5530/ijper.51.4s.113 Correspondence: Dr. Shruti A Wagle, Oriental College of Pharmacy, Sector 2, Plot No 3, 4, 5, Sanpada (W), Navi Mumbai-400705, INDIA. Phone no: 9833155016 E-mail:wagleshruti85@ gmail.com

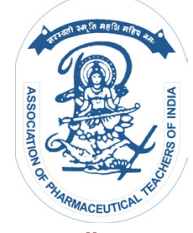

www.ijper.org 
troscopy technique employing inductively coupled plasma to produce excited atoms or ions of metals, each exhibiting a characteristic wavelength upon emission of electromagnetic radiations. ${ }^{5}$ The energy transfer from electrons when they fall to ground state is unique to each element. The compounds under investigation are digested using numerous techniques like treatment with single or combinations of acids and heating process for extraction of desired metals. Also, the interference of other extraneous components in this method is found to be negligible. ${ }^{6,7}$

Hence, a simple and rapid ICP-AES method was developed and validated for determination of Cisplatin levels in biological samples.

\section{MATERIALS AND METHODS}

\section{Reagents and Chemicals}

Cisplatin was a gift sample from Cipla Pharmaceuticals Pvt Ltd (Mumbai, India). Whatmann filter paper No 42 (Quantitative analysis, ashless paper) was purchased from Sigma Aldrich (St. Louis, MO, USA). Analytical grade Hydrochloric acid, Nitric acid and Double distilled water were used for the study.

\section{Instrumentation}

All the measurements were performed using ICP-AES (Model: ARCOS, M/s. Spectro, GmbH, Germany) with radial plasma and maximum $\mathrm{RF}$ generation of $1.6 \mathrm{KW}$, 27.12 MHz. The spectrometer wavelength ranged from $130 \mathrm{~nm}$ to $770 \mathrm{~nm}$ (Platinum metal wavelength: $195 \mathrm{~nm}$ ) with a resolution of 9 picometer and full spectrum scanning ability with a charge couple device (CCD) detector. The metal solution was nebulized into the flame of the instrument and intensity of the energy emitted was recorded, which was proportional to the concentration of platinum metal present in the sample.

\section{Preparation of stock solution}

Cisplatin (15 mg) was accurately dissolved in a volumetric flask of $1000 \mathrm{ml}$ containing $20 \mathrm{ml}$ of aqua regia (combination of $\left.\mathrm{HCl}: \mathrm{HNO}_{3}: 3: 1\right)$. This solution was heated on a water bath at $100^{\circ} \mathrm{C}$ for 2 hours. The resultant solution was filtered through Whatmann filter paper No 42 and diluted with distilled water. The concentration of this platinum stock solution was $9.75 \mu \mathrm{g} / \mathrm{ml}$ which corresponded to $15 \mu \mathrm{g} / \mathrm{ml}$ of Cisplatin.

\section{Calculation of Cisplatin amount by ICP-AES}

It is known that $1.5381 \mu \mathrm{g}$ of Cisplatin $=1 \mu \mathrm{g}$ of platinum. During ICP-AES, platinum metal is analyzed and needs to be converted to the corresponding Cisplatin content by multiplying with the value 1.5381 .

\section{Optimization of acid digestion procedure using several acids}

Different types of acids and acid combinations were added to Cisplatin stock solution and corresponding platinum concentrations were determined by ICP-AES, where samples were analyzed in triplicate.

\section{Optimization of amount of aqua regia for platinum extraction}

Different amounts of aqua regia were added to the stock solution and the corresponding platinum concentrations were determined by ICP-AES, where samples were analyzed in triplicate.

\section{Validation of the ICP-AES analytical method Linearity studies}

Different volumes of stock solutions ranging from 0.25 to $10 \mathrm{ml}$ were taken in $10 \mathrm{ml}$ volumetric flasks. These solutions were diluted with distilled water upto $10 \mathrm{ml}$ to get platinum concentrations in the range of 0.2438 to $9.75 \mu \mathrm{g} / \mathrm{ml}$, corresponding to Cisplatin concentrations of 0.375 to $15 \mu \mathrm{g} / \mathrm{ml}$ respectively. Each of the above solution was analyzed six times for determination of linearity. A graph of average absorbance verses concentration was plotted for estimation of line equation and regression coefficient.

\section{Precision}

The method was validated in terms of reproducibility and repeatability. Low $(0.375 \mu \mathrm{g} / \mathrm{ml})$, medium $(6 \mu \mathrm{g} / \mathrm{ml})$ and high $(15 \mu \mathrm{g} / \mathrm{ml})$ concentrations of Cisplatin in the calibration curve were analyzed. Results for the same were expressed in terms of S.D and \% R.S.D.

\section{Repeatability}

It was investigated by analyzing single solution of Cisplatin at each low $(0.375 \mu \mathrm{g} / \mathrm{ml})$, medium $(6 \mu \mathrm{g} / \mathrm{ml})$ and higher $(15 \mu \mathrm{g} / \mathrm{ml})$ concentrations in the calibration curve repeatedly for six times.

\section{Reproducibility}

It was studied by analyzing solutions of Cisplatin each at low $(0.375 \mu \mathrm{g} / \mathrm{ml})$, medium $(6 \mu \mathrm{g} / \mathrm{ml})$ and high $(15 \mu \mathrm{g} / \mathrm{ml})$ concentrations in the calibration curve. The procedure was repeated six times by preparing fresh solution at each time.

\section{Accuracy}

Cisplatin was accurately weighed, dilutions were made to get the desired concentrations in the linear range and 
the amount of Cisplatin recovered was calculated. The procedure was repeated three times and samples were weighed separately each time. Accuracy was expressed in terms of \% recovery i.e. (Observed concentration / Theoretical concentration $\times 100$ )

\section{Limit of detection}

This was the minimum concentration of Cisplatin that could be detected but not quantified. Concentration of Cisplatin at which smallest peak in the spectrum was observed was noted and the corresponding peak concentration of Cisplatin was calculated from the standard curve.

\section{Limit of Quantification}

It was the minimum concentration of Cisplatin that could be quantified. The smallest peak of Cisplatin that was detected and quantified in the spectrum was observed. The corresponding Cisplatin concentration was calculated from the calibration curve.

\section{Ruggedness}

Ruggedness refers to the reproducibility of results obtained after analysis of sample at different conditions like change in the laboratory, performance of experiment by different analysts or utilization of different set of reagents for the analysis. ${ }^{8}$ Analysis of Cisplatin was carried out by ICP-AES by different analysts in the same laboratory.

\section{Stability of Cisplatin in biological fluids}

Stability of the drug in biological fluids is dependent on a number of factors like physiochemical properties of the drug, storage temperature and conditions and the type of the container closure system. ${ }^{9}$ The conditions which arise during actual handling of the analytical samples should be exemplified in the stability testing procedure.

\section{Freeze Thaw cycle stability of Cisplatin}

Stability of Cisplatin in plasma samples was determined by testing lower and higher concentrations i.e. $0.375 \mu \mathrm{g} / \mathrm{ml}$ and $15 \mu \mathrm{g} / \mathrm{ml}$ in triplicates. The samples were stored in deep freezer at $-20^{\circ} \mathrm{C}$ for 24 hours and thawed as such at room temperature. This freeze thaw cycle was replicated for two more times and then analysis of Cisplatin samples was performed using ICP-AES.

\section{Short term stability of Cisplatin}

Low and high concentrations of Cisplatin $(0.375 \mu \mathrm{g} / \mathrm{ml}$ and $15 \mu \mathrm{g} / \mathrm{ml}$ ) in triplicates were thawed at room temperature, stored at this temperature for around 4 to 24 hours and were analyzed by ICP-AES.

\section{Procedure for determination of Cisplatin in plasma samples and organ tissues}

To plasma $(0.5 \mathrm{ml})$ and homogenates of organ samples (1 gm), known amounts of Cisplatin solution in the range of 3.75 to $15 \mu \mathrm{g} / \mathrm{ml}$ were added and digested with aqua regia under steam bath for 2 hours at $100^{\circ} \mathrm{C}$. The samples were diluted with distilled water upto $10 \mathrm{ml}$ to get concentrations in the range of calibration curve of 0.375 to $15 \mu \mathrm{g} / \mathrm{ml}$. Further, the solutions were filtered through Whatmann filter paper 42 and analyzed by ICP-AES for determination of platinum content. The percent recovery of Cisplatin from plasma and organ samples was calculated as (Practical concentration / Theoretical concentration $\times 100)$.

\section{RESULTS AND DISCUSSION}

Inductively coupled plasma atomic emission method (ICP-AES) was used for quantitation of Cisplatin in biological fluids. ICP-AES possesses linear dynamic range and produces stable and reproducible signals with minimum interference. It is a sensitive (Detection limit: $0.01 \mathrm{ppm}$ for platinum) and selective technique with few matrix interferences. ${ }^{10}$ The scan of platinum metal by ICP-AES is presented in Figure 1.

Cisplatin was analyzed in terms of its platinum content by digestion of the drug to obtain free platinum metal. Different acids like Hydrochloric acid, Nitric acid and their combination (Aqua regia) were tried for extraction of platinum from plasma and tissue samples. It was seen that alone $\mathrm{HCl}$ or $\mathrm{HNO}_{3}$ could extract platinum metal; however the acid combination i.e. aqua regia proved successful in complete removal of platinum from the biological samples. Also, nitric acid was found to be superior to $\mathrm{HCl}$ in extraction of platinum metal (Table 1). Nitric acid is a popular oxidizing agent and prevents formation of any insoluble compounds which is advantageous over hydrochloric acid extraction. Noble metals like platinum are known to exhibit high resistance to

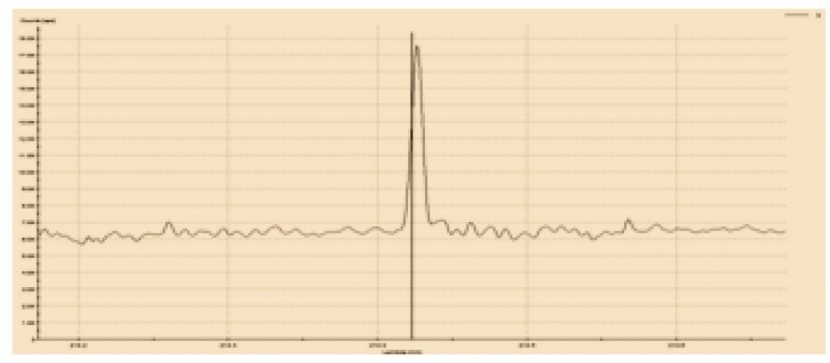

Figure 1: Scan of platinum metal obtained by ICP-AES. 


\begin{tabular}{|c|c|c|c|c|}
\hline \multicolumn{5}{|c|}{ Table 1: Optimization of various acids and acid mixtures for extraction of Platinum. } \\
\hline $\begin{array}{c}\text { Concentration of } \\
\text { Cisplatin stock } \\
\text { solution }(\boldsymbol{\mu g} / \mathrm{ml})\end{array}$ & $\begin{array}{c}\text { Corresponding } \\
\text { Platinum }(\mathrm{Pt}) \\
\text { concentration }\end{array}$ & $\begin{array}{c}\text { Combination of acids/ } \\
\text { acid mixtures }\end{array}$ & $\begin{array}{c}\text { Calculated Cisplatin } \\
\text { concentration }(\boldsymbol{\mu g} / \mathbf{m l})\end{array}$ & $\begin{array}{c}\text { Cisplatin } \\
\text { extracted } \\
(\%)\end{array}$ \\
\hline 15 & 9.7522 & Nitric acid & $14.03 \pm 0.14$ & 93.26 \\
\hline 15 & 9.7522 & Hydrochloric acid & $13.99 \pm 0.46$ & 93.53 \\
\hline 15 & 9.7522 & Aqua regia & $14.96 \pm 0.05$ & 99.73 \\
\hline
\end{tabular}

\begin{tabular}{|c|c|c|c|c|}
\hline \multicolumn{5}{|c|}{ Table 2: Optimization of amount of aqua regia for platinum extraction. } \\
\hline $\begin{array}{c}\text { Concentration of } \\
\text { stock solution }(\boldsymbol{\mu g} / \mathrm{ml})\end{array}$ & $\begin{array}{c}\text { Corresponding } \\
\text { platinum } \\
\text { concentration }\end{array}$ & $\begin{array}{c}\text { Amount of aqua } \\
\text { regia added }(\mathbf{m l})\end{array}$ & $\begin{array}{c}\text { Calculated Cisplatin } \\
\text { concentration }(\boldsymbol{\mu g} / \mathbf{m l})\end{array}$ & $\begin{array}{c}\text { Cisplatin } \\
\text { recovery } \\
\mathbf{( \% )}\end{array}$ \\
\hline 15 & 9.7522 & 10 & $14.43 \pm 0.27$ & 96.20 \\
\hline 15 & 9.7522 & 20 & $15.05 \pm 0.04$ & 100.33 \\
\hline 15 & 9.7522 & 25 & $15.05 \pm 0.14$ & 100.37 \\
\hline 15 & 9.7522 & 30 & $15.02 \pm 0.14$ & 100.13 \\
\hline
\end{tabular}

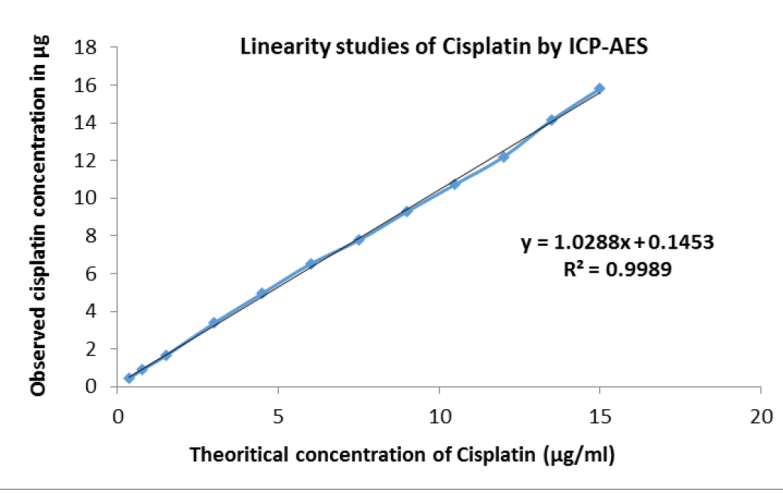

Figure 2: Calibration curve of Cisplatin for estimation by ICP-AES

single acids and hence, are probably not extracted completely in these acids. ${ }^{11}$ Aqua regia is a amalgamation of the above acids wherein the ratio of hydrochloric acid: nitric acid is 3:1 in molar ratio. Platinum extraction was carried out by employing aqua regia by hot digestion method under boiling water bath. ${ }^{12}$

Addition of $20 \mathrm{ml}$ of acid mixture i.e. aqua regia to the stock solution lead to complete platinum extraction. Beyond this amount, the amount of Cisplatin recovered remained constant, indicating that $20 \mathrm{ml}$ of aqua regia proved sufficient for complete platinum extraction (Table 2).

The developed ICP-AES method was validated for various parameters like linearity, precision, accuracy, ruggedness, limit of detection and limit of quantification. ${ }^{13}$ The method was found to be sensitive and linear in the range of 0.375 to $15 \mu \mathrm{g} / \mathrm{ml}$ with a regression coefficient

\begin{tabular}{|c|c|c|}
\hline \multicolumn{3}{|c|}{ Table 3: Linearity studies for Cisplatin estimation by } \\
ICP-AES. \\
$\begin{array}{c}\text { Theoretical } \\
\text { concentration of } \\
\text { Cisplatin }(\mu \mathrm{g} / \mathrm{ml})\end{array}$ & $\begin{array}{c}\text { Observed average } \\
\text { concentration of } \\
\text { Cisplatin }(\mu \mathrm{g} / \mathrm{ml})\end{array}$ & $\begin{array}{c}\text { Standard } \\
\text { deviation } \\
\mathbf{( \pm )}\end{array}$ \\
\hline 0.375 & 0.440 & 0.0255 \\
\hline 0.75 & 0.887 & 0.0563 \\
\hline 1.5 & 1.645 & 0.1639 \\
\hline 3 & 3.375 & 0.2122 \\
\hline 4.5 & 4.949 & 0.0829 \\
\hline 6 & 6.513 & 0.2163 \\
\hline 7.5 & 7.770 & 0.3456 \\
\hline 9 & 9.289 & 0.2316 \\
\hline 10.5 & 10.739 & 0.1659 \\
\hline 12 & 12.198 & 0.4116 \\
\hline 13.5 & 14.148 & 0.5990 \\
\hline 15 & 15.815 & 0.3424 \\
\hline
\end{tabular}

of 0.992 and line equation of $\mathrm{Y}=1.455 \mathrm{X}-2.081$ (Table 3 and Figure 2).

Precision of the analytical method was evaluated in terms of repeatability and reproducibility and the method was found to be precise with \% R.S.D values lower than $2 \%$ (Table 4 and Table 5).

The ICP-AES method was found to be accurate with percent recoveries ranging from 99\%-100\% (Table 6). Limits of detection and quantification were determined to be 0.05 and $0.375 \mu \mathrm{g} / \mathrm{ml}$ respectively. The developed method was also found to be rugged with no signifi- 
cant change in the results of analyzed Cisplatin values by change in the analyst (Table 7 ).

Stability of Cisplatin in plasma was assessed under freeze thaw conditions in the present study. Additionally, benchtop Cisplatin stability at ambient temperature was also determined. As per the regulatory guidelines for bioanalytical method validation, it is essential to determine the stability of analyte in plasma and tissue samples under freeze thaw conditions along with long term stability and short term stability (bench-top). ${ }^{14}$ It was

Freeze Thaw stability of Cisplatin

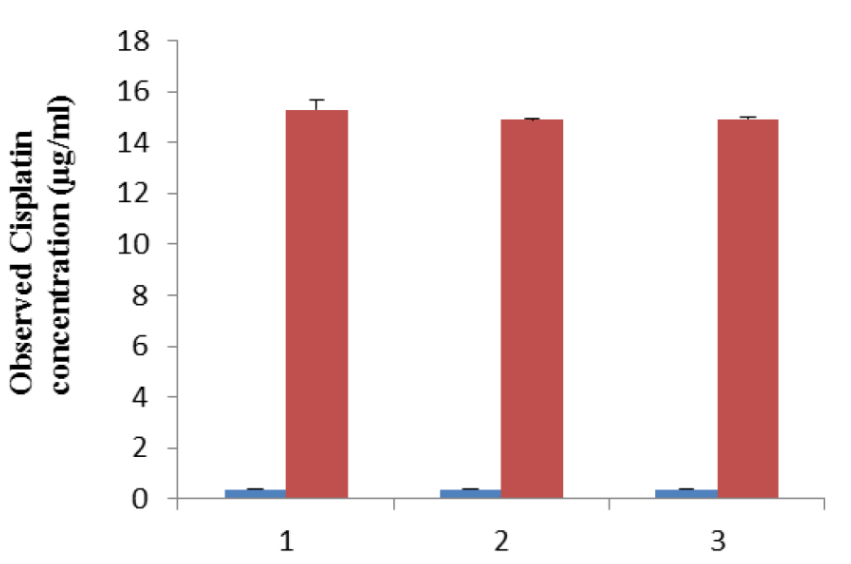

Number of Freeze thaw cycles

Figure 3: Freeze thaw stability testing for Cisplatin observed that Cisplatin was stable under atleast three freeze thaw cycles in plasma. Also, the plasma samples of Cisplatin were stable for a minimum time period of 24 hours under ambient conditions (Figure 3 and Figure 4). Long term stability was not assessed for Cisplatin since the samples were immediately subjected to ICP-AES analysis post platinum metal extraction.

Cisplatin exhibits a susceptibility of reaction with plasma components like glutathione, albumin and cysteine. ${ }^{15}$ Hence; it is detrimental to determine its stability in

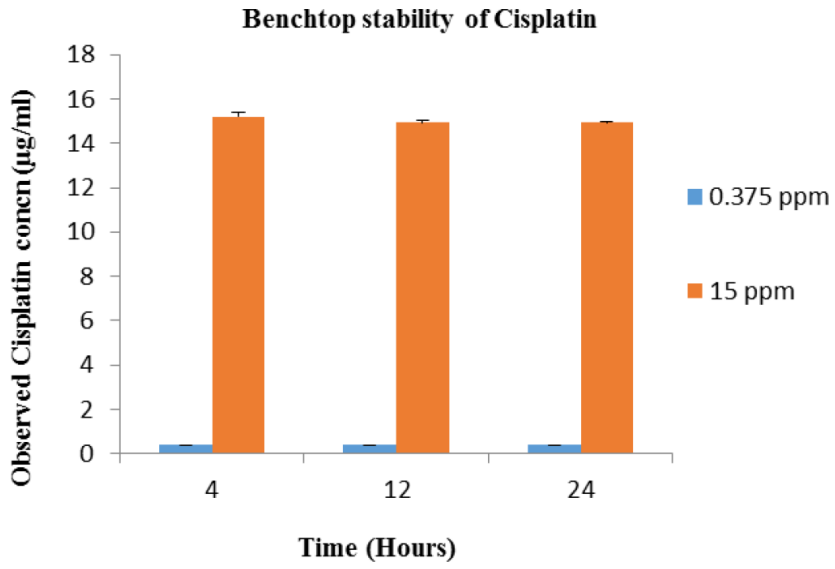

Figure 4: Benchtop stability testing for Cisplatin

\begin{tabular}{|c|c|c|c|c|c|c|c|c|c|}
\hline \multirow{2}{*}{$\begin{array}{l}\text { Sample conc. } \\
\qquad(\mu \mathrm{g} / \mathrm{ml})\end{array}$} & \multicolumn{6}{|c|}{ Obtained concentration $(\mu \mathrm{g} / \mathrm{ml})$} & \multirow[t]{2}{*}{ Average } & \multirow{2}{*}{$\begin{array}{c}\text { Std. Dev } \\
( \pm)\end{array}$} & \multirow{2}{*}{$\begin{array}{c}\text { R.S.D } \\
(\%)\end{array}$} \\
\hline & Set I & Set II & Set III & Set IV & Set V & Set VI & & & \\
\hline 0.375 & 0.37 & 0.38 & 0.36 & 0.37 & 0.37 & 0.37 & 0.37 & 0.006 & 1.626 \\
\hline 6 & 6.12 & 6.02 & 6.15 & 6.02 & 6.13 & 5.99 & 6.09 & 0.066 & 1.088 \\
\hline 15 & 15.1 & 14.99 & 14.97 & 14.91 & 15.09 & 14.89 & 15.02 & 0.070 & 0.466 \\
\hline
\end{tabular}

\begin{tabular}{|c|c|c|c|c|c|c|c|c|c|}
\hline \multirow{2}{*}{$\begin{array}{l}\text { Sample conc. } \\
\qquad(\mu \mathrm{g} / \mathrm{ml})\end{array}$} & \multicolumn{6}{|c|}{ Obtained concentration $(\mu \mathrm{g} / \mathrm{ml})$} & \multirow{2}{*}{ Average } & \multirow{2}{*}{$\begin{array}{l}\text { Std. Dev } \\
( \pm)\end{array}$} & \multirow{2}{*}{$\begin{array}{l}\text { R.S.D } \\
(\%)\end{array}$} \\
\hline & Set I & Set II & Set III & Set IV & Set V & Set VI & & & \\
\hline 0.375 & 0.37 & 0.38 & 0.37 & 0.37 & 0.36 & 0.37 & 0.373 & 0.004 & 1.124 \\
\hline 6 & 6.11 & 5.90 & 5.98 & 5.99 & 6.21 & 6.16 & 6.062 & 0.117 & 1.935 \\
\hline 15 & 15.1 & 15.12 & 14.97 & 14.98 & 14.99 & 15.18 & 15.076 & 0.102 & 0.682 \\
\hline
\end{tabular}

\begin{tabular}{|c|c|c|c|c|c|c|}
\hline \multirow{2}{*}{$\begin{array}{l}\text { Theoretical Cisplatin } \\
\text { concentration }(\mu \mathrm{g} / \mathrm{ml})\end{array}$} & \multicolumn{3}{|c|}{ Observed concentration $(\mu \mathrm{g} / \mathrm{ml})$} & \multirow[t]{2}{*}{ Average } & \multirow{2}{*}{$\begin{array}{l}\text { Std Dev } \\
( \pm)\end{array}$} & \multirow{2}{*}{$\begin{array}{c}\text { Recovery } \\
(\%)\end{array}$} \\
\hline & Set I & Set II & Set III & & & \\
\hline 0.375 & 0.376 & 0.381 & 0.36 & 0.374 & 0.006 & 99.99 \\
\hline 6 & 6.145 & 5.991 & 5.89 & 6.008 & 0.128 & 100.14 \\
\hline 15 & 15.05 & 14.899 & 14.99 & 14.982 & 0.076 & 99.88 \\
\hline
\end{tabular}


Table 7: Ruggedness of ICP-AES method for Cisplatin analysis.

\begin{tabular}{|c|c|c|c|c|}
\hline Parameter & Analyst & $\begin{array}{c}\text { Theoretical Cisplatin } \\
\text { concentration }(\mu \mathrm{g} / \mathrm{ml})\end{array}$ & $\begin{array}{c}\text { Observed Cisplatin } \\
\text { concentration }(\boldsymbol{\mu g} / \mathrm{ml})\end{array}$ & $\begin{array}{c}\text { Std Dev } \\
(\mathbf{\pm})\end{array}$ \\
\hline \multirow{3}{*}{$\begin{array}{c}\text { Change in } \\
\text { analyst }\end{array}$} & \multirow{3}{*}{ Analyst A } & 0.375 & 0.38 & 0.00 \\
\cline { 3 - 5 } & \multirow{2}{*}{ Analyst B } & 7.5 & 7.52 & 0.01 \\
\cline { 3 - 5 } & & 15 & 15.23 & 0.09 \\
\cline { 3 - 5 } & & 0.375 & 0.34 & 0.05 \\
\cline { 3 - 5 } & & 7.5 & 7.54 & 0.04 \\
\hline
\end{tabular}

\begin{tabular}{|c|c|c|c|c|c|c|c|}
\hline \multicolumn{7}{|c|}{ Table 8: Recovery studies of Cisplatin from Biological samples. } \\
\hline \multirow{7}{*}{$\begin{array}{c}\text { Concentration of } \\
\text { Cisplatin }(\boldsymbol{\mu g} / \mathbf{m l})\end{array}$} & \multicolumn{7}{|c|}{ Recovery from biological samples (\%) } \\
\cline { 2 - 8 } & Liver & Plasma & Heart & Lung & Spleen & Kidney & Brain \\
\hline 0.375 & 96.14 & 98.00 & 95.00 & 95.00 & 96.13 & 95.11 & 95.23 \\
\hline 0.75 & 97.23 & 95.00 & 95.50 & 95.43 & 97.35 & 97.56 & 96.33 \\
\hline 1.5 & 95.00 & 95.67 & 95.00 & 95.38 & 97.35 & 97.88 & 96.47 \\
\hline 3 & 95.50 & 95.75 & 95.25 & 95.22 & 96.53 & 98.71 & 99.87 \\
\hline 4.5 & 96.00 & 95.80 & 95.80 & 94.98 & 95.00 & 97.11 & 96.41 \\
\hline 6 & 95.49 & 96.17 & 97.83 & 96.65 & 96.40 & 96.22 & 97.28 \\
\hline 7.5 & 95.13 & 95.86 & 95.71 & 98.34 & 96.11 & 97.44 & 98.45 \\
\hline 9 & 96.28 & 95.50 & 95.25 & 99.17 & 98.45 & 98.11 & 98.57 \\
\hline 10.5 & 98.94 & 95.78 & 98.78 & 96.55 & 98.55 & 97.89 & 97.31 \\
\hline 12 & 95.44 & 95.10 & 98.80 & 95.10 & 97.99 & 97.22 & 97.86 \\
\hline 13.5 & 94.50 & 98.17 & 95.10 & 95.34 & 95.11 & 96.45 & 95.12 \\
\hline 15 & 99.10 & 97.23 & 98.467 & 95.38 & 96.19 & 96.77 & 95.44 \\
\hline
\end{tabular}

plasma and biological fluids. The percent recoveries of Cisplatin from biological samples ranged from 95-99\% from plasma samples and highly perfused organs like liver, spleen, heart, kidney, lungs and brain (Table 8).

\section{CONCLUSION}

The developed inductively coupled plasma-atomic emission spectrometric technique was found to be simple, specific and robust for routine analysis of Cisplatin. Hence, using the developed and validated ICP-AES method, analysis of Cisplatin in biological matrices could be carried out without any interference and with sufficient accuracy and precision.

\section{ACKNOWLEDGEMENT}

The authors are thankful to Cipla Pvt Ltd, Mumbai for providing Cisplatin sample as well as sponsoring the present research work.

\section{CONFLICT OF INTEREST}

The authors have no conflict of interest.

\section{REFERENCES}

1. Florea MA, Busselberg D. Cisplatin as an Anti-Tumor Drug: Cellular Mechanisms of Activity, Drug Resistance and Induced Side Effects. Cancers. 2011; 3(1):1351-71. https://doi:10.3390/cancers3011351.

2. Shrikhande SS, Jain DS, Athawale RB, Bajaj AN. Development and Validation of U.V Spectrophotometric method for Estimation of Cisplatin in Pharmaceutical formulations. Indian Drugs. 2014; 51(7):23-30.

3. Perry BJ, Balazs RE, ICP-MS method for the determination of platinum in suspensions of cells exposed to Cisplatin. Anal. Proc. 1994; 31: 269-71. https://doi:10.1039/AI9943100269.

4. Kaushik KH, Sripuram VK, Bedada S, Reddy NY, Priyadarshini I, Devarakonda KR. A simple and sensitive validated HPLC method for quantitative determination of cisplatin in human plasma. Clinical Research and Regulatory Affairs. 2010; 27(1):1-6. http://dx.doi.org/10.3109/10601330903490462.

5. Montaser A, Golightly DW. Inductively Coupled Plasmas in Analytical Atomic Spectrometry. $2^{\text {nd }}$ Ed., New York, VCH Publishers. 1992.

6. Verbeke JS, Detaevernier MR, Denis L, Massart DL. The determination of platinum in biological fluids by means of graphite furnace atomic absorption spectroscopy. Clin. Chim. Acta. 1981; 113: 329- 33. https://doi. org/10.1016/0009-8981 (81)90287-4

7. Jones $\mathrm{AH}$. Determination of platinum and palladium in blood and urine by flameless atomic absorption spectroscopy. Analytical Chemistry. 1976; 48(11):1472-4. https://doi:10.1021/ac50005a015.

8. Burns DT, Danzer K, Townshend A. A Tutorial Discussion of the use of the terms "Robust" and "Rugged" and the Associated Characteristics of "Robustness" and "Ruggedness" as used in Descriptions of Analytical Procedures. Journal of the Association of Public Analysts. 2009; 37:40-60.

9. Chamberlain J. The analysis of drugs in biological fluids. $2^{\text {nd }}$ Ed., New York, CRC Press, 1995. 
10. Ash P. Final analysis: Accurate and Precise determination of Platinum in solution by ICPES. Platinum Met Rev. 2008; 52(3): 205-6. https://doi. org/10.1595/147106708X333836.

11. Balcerzak M. Sample digestion methods for determination of traces of precious metals by spectrometric techniques. Analytical Sciences. 2002; 18(7): 737-50. PMID: 12137367.

12. Huynh VT, Binauld S, de souza PL, Stenzel MH. Acid Degradable Cross-Linked Micelles for the Delivery of Cisplatin: A Comparison with Nondegradable Cross-Linker. Chem. Mater. 2012; 24(16):3197-211. https:// DOI: 10.1021/cm301556b.
13. Vallapragada VV, Inti G, Ramulu JS. A Validated Inductively Coupled PlasmaOptical Emission Spectrometry (ICP-OES) Method to Estimate Free Calcium and Phosphorus in in vitro Phosphate Binding Study of Eliphos Tablets. American Journal of Analytical Chemistry. 2011;2(06):718-25. https:// doi:10.4236/ajac.2011.26082.

14. Wang J, Nowatzke W, Ma M. Current industrial practices and regulatory requirements to assess analyte and reagent stability using ligand-binding assays. Bioanalysis. 2015; 7(11):1371-84. https:// doi:10.4155/bio.15.52.

15. Figg WD, Mcleod HL. Handbook of Anticancer Pharmacokinetics and Pharmacodynamics. $1^{\text {st }}$ Ed. New York, Humana Press, 2004.

\section{PICTORIAL ABSTRACT}

Cisplatin conversion to platinum metal by aqua regia

Determination of Platinum concentration by ICP-AES

Validation of the developed

\section{SUMMARY}

- $\quad$ ICP-AES method could be successfully applied for estimation of Cisplatin in biological samples

- The developed method was found to be sensitive and linear in the concentration range of 0.375 to $15 \mathrm{ppm}$.

\section{About Authors}

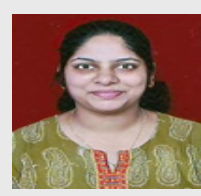

Dr. (Mrs.) Shruti Wagle: Is working as an Assistant Professor in Pharmaceutics at Oriental College of Pharmacy, Mumbai. She has three years of teaching and seven years of research experience. She has authored and co-authored about thirteen publications and has one patent to her credit. She has participated and presented papers in several national conferences and attended several seminars and workshops.

Cite this article: Wagle SA, Jain D, Rathod S, Athawale R, Bajaj A. Development and Validation of Inductively Coupled Plasma Atomic Emission Spectroscopy [ICP-AES] Analytical Method for Estimation of Cisplatin in Biological Samples. Indian J of Pharmaceutical Education and Research. 2017;51(4S):S783-S9. 